This is an accepted manuscript of an article published by Taylor \& Francis in Teaching in Higher Education on 27/11/2019, available online:

https://www.tandfonline.com/doi/full/10.1080/13562517.2019.1696296

Full citation:

Acai, A., Mercer-Mapstone, L., \& Guitman, R. (2019). Mind the (gender) gap:

Engaging students as partners to promote gender equity in higher education.

Teaching in Higher Education. https://doi.org/10.1080/13562517.2019.1602761 


\title{
Mind the (gender) gap: engaging students as partners to promote gender equity in higher education
}

\author{
Anita Acai
}

Department of Psychology, Neuroscience \& Behaviour; Office of Education Science, Department of Surgery; and Paul R. MacPherson Institute for Leadership, Excellence \& Innovation in Teaching, McMaster University, Hamilton, Ontario, Canada https://orcid.org/0000-0002-9901-2946

Lucy Mercer-Mapstone

Sustainable Minerals Institute, University of Queensland, Brisbane, Australia ${ }^{1}$ https://orcid.org/0000-0001-7441-6568

\section{Rachel Guitman}

Arts \& Science Program and Paul R. MacPherson Institute for Leadership, Excellence \& Innovation in Teaching, McMaster University, Hamilton, Ontario, Canada https://orcid.org/0000-0002-9860-1204

Correspondence to: Anita Acai, A.N. Bourns Science Building, Room 131, 1280 Main Street West, Hamilton, Ontario, Canada, L8S 4M1. E-mail: acaia@mcmaster.ca

\footnotetext{
${ }^{1}$ This author moved institutions twice during the research and peer review process. An additional previous institution was the Institute for Academic Development, University of Edinburgh, Edinburgh, Scotland, United Kingdom. She is currently at the University of Technology Sydney, Sydney, Australia.
} 


\section{Mind the (gender) gap: engaging students as partners to promote gender equity in higher education}

Gender inequity remains a critical issue in higher education. We explored the proposition that engaging students as partners $(\mathrm{SaP})$, an increasingly adopted approach to student engagement, may present one approach to improving gender equity by fostering agency and leadership for women. First, we analysed the gender distribution of authors of SaP scholarship spanning 202 articles published in six academic journals over the past five years. Women were more likely to author (70\%) and lead (76\%) SaP publications. Second, we used collaborative autoethnography to explore our experiences as three women SaP practitioners. Affirmative partnerships built our agency to assert our voices and empowered us to advocate for gender equity. These data indicate that SaP may present one approach to promoting gender equity by creating 'brave spaces' and 'sites of resistance' against gendered norms in academia.

Keywords: students as partners; gender; feminism; diversity; equity; higher education

\section{Introduction}

Without a doubt, the gender gap [in academia] is still high. ... There is no gender neutrality in academia ... On the contrary, institutions of higher education ... are highly gendered in practices as well as in the culture of the organization. (Klein, 2016, p. 147)

Diversity and inclusivity have become critical issues in higher education internationally.

While universities strive to achieve environments that support and include diverse students and staff, the reality — as the above quote indicates—often falls short. Gender equity has been of significant focus in recent years as the rate of women enrolling in tertiary education has begun to surpass that of men in most Western countries. Within 
the European Union (2012), for example, three fifths of graduates were women. This trend is the same in Australia (Workplace Gender Equality Agency, 2018) and North America (Hugo Lopez \& Gonzalez-Barrera, 2014). The number of women in academic staff positions has not seen a corresponding increase, however, particularly in senior academic and leadership positions, which continue to be dominated by men (American Association of University Professors, 2009; European Commission, 2012; Jarboe, 2016b). The barriers faced disproportionately by women do differ across disciplines. As one example, these challenges are significant in science, technology, engineering, and mathematics (STEM) fields where a gender imbalance exists even at lower levels of education and worsens further up the academic pipeline (Hango, 2013). How, then, do we better support women in higher education to continue on into academic and leadership roles within a male-dominated academy?

Students' experiences of universities during their studies seems a logical place to begin in better facilitating such support as these experiences will have an impact on their aspiration to, and success in, continuing onto an academic career. Even if students choose not to continue on in academia, the skills they develop can have a significant impact on their future career success and satisfaction (Borwein, 2014). Student engagement — including emotional, cognitive, and behavioural connection to learning (Fredricks, Blumenfeld, \& Paris, 2004) — is widely acknowledged as being critical to students' sense of belonging and success at university and beyond (Kahu \& Nelson, 2018). One approach to fostering student engagement that has seen rapid uptake across international contexts is to engage students as partners ( $\mathrm{SaP})$ in teaching and learning. Research exploring SaP increasingly cites that engaging students in partnerships with academics (faculty in the North American context) and staff makes the inclusion of diverse and often marginalised voices core to high education (e.g., Bovill, Cook-Sather, 
Felten, Millard, \& Moore-Cherry, 2016; Cook-Sather \& Agu, 2013; Mercer-Mapstone $\&$ Mercer, 2017). It has been argued that, with widespread uptake, such practices could move universities toward developing inclusive learning cultures (e.g., Healey, Flint, \& Harrington, 2014; Matthews, Cook-Sather, \& Healey, 2018).

\section{SaP: an approach to foster gender equity?}

We propose that SaP may be one approach to better foster gender equity in higher education. $\mathrm{SaP}$ is a 'collaborative, reciprocal process through which all participants have the opportunity to contribute equally, although not necessarily in the same ways, to curricular or pedagogical conceptualization, decision-making, implementation, investigation, or analysis' (Cook-Sather, Bovill, \& Felten, 2014, pp. 6-7). SaP aims to reconceptualize the power relationships between staff and students-re-envisioning partners as co-creators and co-learners with different but equally valuable expertise to bring to higher education (Cook-Sather et al., 2014; Cook-Sather \& Luz, 2015). SaP is a values-based ethos underpinned by principles of respect, reciprocity and shared responsibility (Cook-Sather et al., 2014; Healey, Flint, \& Harrington, 2016).

Healey et al. (2014) developed a model of student partnership, articulating that students can engage as partners across four overlapping categories: learning, teaching, and assessment; subject-based research and inquiry; curriculum design and pedagogic consultancy; and the scholarship of teaching and learning. Students can engage in partnership with academics, professional staff, senior management, other students or student unions, as well as with members of the community or professions beyond universities (Healey et al., 2014). Although much SaP research has been conducted in North America, the United Kingdom, and Australia, focus is beginning to increase in other contexts, such as in Malaysia, as well (Kaur, Awang-Hashim, \& Kaur, 2018). 
The skills and mindset required to engage in partnerships are those that go beyond, and are often overlooked, in formal curricula. For example, effective partnerships require partners to enact principles of inclusivity, power-sharing, dialogue, reflection, embracing uncertainty, and ethical behaviour (Matthews, 2017). The outcomes gained by students and staff from engaging in partnership can include increased engagement in teaching and learning, improved confidence and self-efficacy, the building of trust-based and power-sharing relationships and positive impacts on identity development (Allin, 2014; Cook-Sather, 2015; Mercer-Mapstone et al., 2017a). Additionally, engaging in SaP can encourage students to step outside normative conceptions of students as passive consumers by enabling them to value their own voice and expertise, navigate conflict and uncertainty, overcome adversity, and take on leadership roles (Dunne \& Zandstra, 2011; Marquis, Black, \& Healey, 2017; Mathrani, 2018; Mercer-Mapstone, Dvorakova, Groenendijk, \& Matthews, 2017b).

Our anecdotal experiences of partnership have been that they can create spaces in which voices that have historically been marginalised, such as those of students and women, are amplified. We explored this link between gender equity ${ }^{2}$ and $\mathrm{SaP}$ in the studies below, guided by the question: To what extent are women's voices represented as part of knowledge production in SaP, and how does this shape their experiences in higher education? We draw on the work of postcolonial feminist scholars (e.g., Carr, 1993; Haraway, 1988; Mohanty, 1989) to argue that the notion of voice-whose voices are heard and whose are silenced — is critical in the movement toward gender equity in higher education, particularly in fields like SaP where the focus is on enhancing

\footnotetext{
${ }^{2}$ We acknowledge that a significant limitation in this framing is its focus on 'women' as a category, which reinforces the gender binary and does not include other factors that influence gender construction, such as race. However, given the scope of this investigation and the available data (which predominantly operates in an oversimplified, binarized lens), we chose to use this framing. Particularly given the dearth of existing research that addresses gender at all, this is nonetheless a useful question to ask.
} 
learning and teaching. A focus on amplifying women's voices does not mean that we are ignorant of the broader, systems-level changes that are needed to create more equitable systems of higher education (e.g., by addressing issues such as homosociability or blatant discrimination). However, we believe that this strategy is a good starting point to catalyse some of the cultural change of which we speak.

Feminist scholars such as Donna Haraway (1988) and Chandra Mohanty (1989) have argued that our personal experiences, while necessarily subjective, are a valid and important lens for understanding social dynamics and history. For example, Haraway (1988) wrote that 'feminist objectivity means quite simply situated knowledges'; thus, articulating our situated knowledge 'allows us to become answerable for what we learn how to see' (p. 583). Similarly, in writing about Audre Lorde and the politics of voice, feminist writer Brenda Carr (1993) pointed out that:

... speaking out is the sign of, and often, a literal means of, intervention in oppressive systems. This equation between speaking out and acting up, voice and public visibility, has been central to twentieth-century activism that coheres around group identity formation - for example, the black power, women's liberation, and gay pride movements. Such agency is contingent on finding a communal voice [as] opposed to what Jo Spence calls 'structured and structuring silences.' (p. 133)

Carr additionally wrote that 'Lorde's invocation of her "voice/presence" [is] a provisional assertion of strategic authority; she "intends" to intervene in the symbolic order with her alternative signifying practice. Such an authority de-authorizes those with capital A/Authority and opens up the cultural space for others speaking' (p. 135).

Thus, using voice as one indicator of gender representation, we aimed to bring a new lens to the SaP literature - that of gender and feminism — as a connection that has predominantly been underexplored in this field. This article is, to our knowledge, one of the first empirical studies to explicitly explore the role of gender in the SaP context. As 
such, our focus is necessarily broad. Given the distinct dearth of such research in existing SaP literature, we aimed to take an exploratory approach to laying a foundation for future research in this important area.

\section{Methods}

We approached our research question in two ways. The first was to collect quantitative data on the gender distribution of authors publishing on the topic of SaP through an analysis of a relevant body of literature (Study One). This study was designed to establish broad trends on the gender ratio of those contributing their voices to knowledge creation in SaP. The second approach was to collect qualitative data on our experiences as women who actively publish on the topic of SaP (Study Two). We studied our own experiences using collaborative autoethnography as we felt that they might offer deeper insight into the trends elucidated in the first study. These studies were designed to be complementary in examining the relationship between gender and $\mathrm{SaP}$ — one looking at broad trends and the other focusing on individual experiences. This design was inspired by Burke (2015), who combined a literature analysis of Teaching in Higher Education with qualitative data to explore gender issues in higher education pedagogies. We note that, in the present article, we use 'gender' and associated terms (i.e., woman, man, non-binary) to refer to 'the socially constructed roles, behaviours, expressions and identities of girls, women, boys, men, and gender diverse people' (Canadian Institutes of Health Research, 2018, para. 2).

\section{Study one: quantitative analysis of SaP authorship}

Drawing on the methods used by Filardo et al. (2016), the aim of this study was to determine the gender distribution of authors and impact of journal articles explicitly framed as focusing on SaP. Although we acknowledge that publication is not the only 
measure of practice and knowledge creation in academia, these are still predominantly shaped by those who author academic discourses through publication (Aiston \& Jung, 2015). Thus, we felt that our methods were appropriate for gaining insight into the extent to which women and other minorities have a voice and hold positions of leadership in the process of knowledge creation in SaP.

\section{Data collection}

Inclusion and exclusion criteria. Kennedy (2007) suggested that any review of published literature be bounded by clear criteria for what work was included and excluded. We selected journals for inclusion that have a focus on publishing student engagement and SaP scholarship based on the rationale that these journals would contain the highest concentration of $\mathrm{SaP}$ research, since $\mathrm{SaP}$ is still an emerging field. The six journals were: International Journal for Academic Development (IJAD); International Journal for Students as Partners (IJSaP); The Journal of Educational Innovation, Partnership, and Change (JEIPC); Student Engagement in Higher Education Journal (SEHEJ); Teaching \& Learning Inquiry (TLI); and Teaching and Learning Together in Higher Education (TLTHE). Four of these are explicitly student engagement and partnership-focused (IJSaP, JEIPC, SEHEJ, and TLTHE) while two (IJAD and TLI) include broader foci but are known to publish SaP work.

We screened each article published in these journals to determine if it was relevant for inclusion in the study based on the following criteria: (1) published between 2013 and 2017, (2) published in English, (3) self-identified as focusing on SaP (or related terms such as student-staff partnership and students as co-creators), and (4) in the context of higher education. This process was adapted from previous studies, such as Amundsen and Wilson (2012). All article types were eligible for inclusion except for 
introductions published in one journal. ${ }^{3}$ In the event that we were unable to determine if an article met the criteria, we discussed until a consensus was reached.

Variables of interest. For each included article, we recorded title; authors; date; volume; issue; article type; number of authors identified as women, men, non-binary, or unidentified; and first author gender identity. As measures of article and author impact, we used Google Scholar and ResearchGate ${ }^{4}$ to search for and record citation counts for each article and h-indices for all first authors. The h-index is considered a better standard for measuring scholarly output than article or citation counts alone, as it accounts for both overall productivity and citation impact (Hirsch, 2005).

We adopted the approach used by Filardo et al. (2016) to determine gender identity. In a number of cases, we knew the author and were able to identify their gender identity directly. In cases where we were unfamiliar with an author, we looked for instances where the author used pronouns (i.e., 'she/her' for women, 'he/him' for men, and 'they' [used in a gender-neutral context] or 'zi/zer' [or related variants] for gender non-binary). Sources included author biographies in the article, biographies on institutional websites, news articles, and professional or social media sites. Author gender identity was listed as unknown where no information could be found. We acknowledge that this method is limited in comparison to having the authors themselves explicitly self-identify, but it was necessary for feasibility purposes.

\footnotetext{
${ }^{3}$ These were authored primarily by the sole editor of that journal and were deemed not to be representative of the overall sample.

${ }^{4}$ Google Scholar was used to determine citation counts and h-indices where possible, as it is a more comprehensive database. However, if an author did not appear to have a Google Scholar profile, we performed a second search for their h-index using ResearchGate.
} 


\section{Data analysis}

We conducted chi-square goodness-of-fit tests to determine if there were significant differences between the proportions of women and men authoring and first-authoring SaP-related articles using IBM SPSS v. 25. We conducted a linear regression to determine statistically significant trends in authorship and first authorship over time, and two-tailed independent t-tests with equal variances assumed to compare the citation counts and h-indices of women and men. A significance level of $p<.05$ was assumed for all tests.

\section{Study two: collaborative autoethnography about experiences in SaP}

We sought to add a level of depth to this study by understanding not only gender trends across the literature, but also how some women who contribute to that literature experience gender in partnership. To do this, we followed the example of Seale, Gibson, Haynes, and Potter (2015) by analysing reflective narratives from the authorship team. Collaborative autoethnography was used to structure this reflective process.

Autoethnography is a method of self-study that situates the researcher as the focus of the research (Reed-Danahay, 1997). Collaborative autoethnography replicates this self-study involving multiple researchers as participants. Chang, Ngunjiri, and Hernandez (2013) argued the value for collaborative autoethnography, describing it as: 'A group of researchers pooling their stories to find some commonalities and differences ... to discover the meanings of the stories in relation to their sociocultural contexts' (Chang et al., 2013, p. 17). As three women partnership scholars functioning across countries, disciplines, job roles, and institutions, the breadth of our sociocultural experiences seemed appropriate for exploration in this context. 


\section{Guided reflective narratives}

Collaborative autoethnography using personal reflection is an approach that can be used to understand of the situated experiences of small groups of people (Clandinin \& Connelly, 2000). We sought to understand our own experiences of gender in partnership by writing individual autoethnographic reflections that were guided by a reflective framework to ensure a robust, systematic process. This framework posed a series of questions designed to explore our experiences of gender in partnership in a process that moved through stages of description, reflection, analysis, learning, and action (adapted from University of Brighton, 2011). The full framework is outlined in Appendix A. Each of us wrote two reflections answering all questions. One reflection focused on a positive experience and the other on a negative experience of partnership, each where we perceived our gender identity to be salient. Each reflection was approximately 1,500 words, resulting in a full dataset of 9,000 words.

\section{Analysis}

We used thematic analysis to analyse the dataset, employing the Braun and Clarke (2006) six-phase approach of data familiarisation, initial codes, theme identification, theme review, theme definition and naming, and report assembly. We took a theoretical approach to this thematic analysis rather than an inductive one. Thus, our analysis was guided by the questions in our framework, which were based on previous theoretical or empirical themes across the partnership literature. The second author conducted the initial analysis. Results were then cross-checked in a second analysis by the first author to ensure alignment in themes. Where results diverged between these two analyses, themes were discussed and iteratively revised and reapplied until complete analytic agreement was reached. We report a relevant subsection of these results below to compliment the quantitative dataset. 


\section{Results}

\section{Study one: quantitative analysis of SaP authorship}

Across the six journals including all volumes and issues over the past five years, a total of 460 articles were considered for inclusion. Of these, 202 articles (44\%) written by 512 authors met the inclusion criteria. Ninety-one percent $(n=467)$ of these authors were unique, having authored only one article in the sample. Of the authors with more than one article $(n=45)$, the average number of articles per author was 2.56 (range 2-9).

Overall, women were significantly more likely to author an article in our sample than were men, $\chi^{2}(1, N=512)=82.88, p<.001$. Across the 202 articles analysed, $70 \%(n=359)$ of the total 512 authors were women. Articles were also significantly more likely to have a woman first author, $\chi^{2}(1, N=202)=55.62, p<.001$, with $76 \%(n=154)$ of the total 202 articles being first authored by women. No articles were categorized as being authored by gender non-binary authors nor were there any authors whose gender could not be determined.

Table 1 illustrates the percentage of all authors and first authors who are women in each of the six journals. In all six of the journals, women constituted more than twothirds of all first authorship. Women constituted the majority of authors and first authors across all journals, ranging from $66-77 \%$ and $55-87 \%$, respectively. A simple linear regression with year as the predictor variable and percentage of women authors as the criterion variable did not show any significant differences in trends across the five-year period, all authors: $b=-.41, t(3)=-.79, p=.49$, first authors: $b=-.73, t(3)=-1.85, p=$ .16 (Table 2 and Figure 1).

$<$ Place Table 1 about here $>$ $<$ Place Table 2 and Figure 1 about here $>$ 
Table 3 and Figure 2 illustrate the percentage of all authors and first authors who are women, sorted by article type. The most common article types in the sample were case studies $(n=72,36 \%)$, research articles $(n=62,31 \%)$, and reflections $(n=37$, $12 \%)$. Each of these article types were more likely to be authored by women than by men. However, the largest gender difference in authorship was found among reflections, $83 \%$ of which were authored by women and $17 \%$ of which were authored by men. Conversely, the smallest gender difference in authorship was found among opinion pieces, which were equally as likely to be authored by women as they were by men. $<$ Place Table 3 and Figure 2 about here $>$

Our analysis of article impact revealed an average of 2.90 citations per article $(S D=8.09)$, with no significant difference in citation counts between articles firstauthored by women $(M=3.02, S D=8.37)$ and by men $(M=2.53, S D=7.18), t(200)=$ $.36, p=.72$. As shown in Table 1, publication venue appeared to influence the number of citations, with average counts ranging from 0.65 (TLTHE) to 15.71 (IJAD). The same was true for article type, also shown in Table 3, with average counts ranging from 0 (book reviews) to 5.50 (editorials/forewords/prefaces). ${ }^{5}$

The average h-index of the first authors in our sample was $7.44(S D=7.35)$, although an h-index could only be determined for $36 \%(n=62)$ of the 173 unique first authors. We were unable to locate a Google Scholar or ResearchGate profile for the remaining $64 \%(n=111)$ of first authors. There was no significant difference between the h-indices of women first authors $(M=7.07, S D=6.41)$ and men first authors $(M=$ $8.58, S D=9.40), t(60)=.73, p=.47$.

\footnotetext{
${ }^{5}$ In our calculation of average citation counts, we removed one book review with 335 citations as this extreme outlier would have unduly inflated our averages.
} 


\section{Study two: collaborative autoethnography about experiences in SaP}

Three themes resulting from the analysis of our reflective narratives resonated most strongly with results from Study One. These themes are summarized below with illustrative quotes, and points of resonance between datasets highlighted.

\section{Countering traditional higher education/gendered power hierarchies}

Certain experiences described in our reflections were perceived to counter traditional higher education and/or gendered power hierarchies:

By serving as an advocate for women in a field that is still very dominated by men,

Ellen [a staff partner] was able to go against traditional power hierarchies. This

illustrates a certain amount of risk-taking and vulnerability, which is what's needed to truly create change.

This process of countering academic norms aligns with the ways in which the aforementioned results describe trends where women take on the majority of leadership roles in SaP publishing — which historically, and in some fields currently, has been a male-dominated space.

In our experiences, such instances were often seen to occur through acts of nontraditional power sharing, or in other words, behaviours that distribute power equally among students and staff. In our reflections, such acts were most often in situations where one woman was perceived to be a mentor for another:

My supervisor had taught me in a course the previous semester, so there was a residual power dynamic from that, and a differential in our qualifications (as an undergrad, it does feel intimidating to talk to a $\mathrm{PhD})$ ! However, ... I had ownership over the project, and she did not impose her authority or views or push me in specific directions at all. It felt like a very equitable partnership-like relationship. It felt like we acknowledged we had different levels of expertise but still interacted with the same level of authority/power. 
We perceived such partnerships to build a sense of leadership and agency for each of us in different ways. This agency was expressed within and outside of partnerships through the assertion of our voices, as described in the following section. The development of women's agency through voice could be one aspect of partnership that contributes to the trends in publishing described in Study One.

\section{Empowerment through voice}

Whether or not we felt we had power in partnership contexts was most often defined by our capacity to have a voice. Empowerment was often related to power holders creating space for others to have a voice:

... the way she treated me diffused much of the intimidation because I did not feel there was a strong attachment to authority or hierarchy. The lack of enforced power dynamics made me much more at ease and influenced my behaviour to be more open and communicative. It made it easier to bring up concerns honestly.

The act of communication itself was sometimes an act of empowerment, where individuals from historically marginalised groups in academia (e.g., women or nonbinary persons) were able to assert their voices:

I took the time not only to make my voice heard but to ensure the voices of others in the room were equal.

The notion of voice being linked to power compliments Study One results by providing dual perspectives on the ways in which partnership can create space and develop skills for women to assert their voices and to contribute to shaping scholarly discourses.

\section{Stronger support and advocacy for gender equity}

We saw stronger support and advocacy for gender equity as a result of our partnership experiences. This was an outcome that we each saw ourselves enacting within partnership and translated to contexts outside of partnership. The positive affirmation or 
role modelling of a strong woman partner meant that we felt more confident in enacting those values ourselves:

I now find myself taking a more active role in supporting my female colleagues.

The negative emotions we felt when disempowered also were seen to be a source of motivation that drove a resolve to support women colleagues and advocate for gender equity more broadly:

I'm pissed off. But in a good way. Not in a way that makes me cry but in a way that empowers me. That drives me to stand up for myself, for others, to make sure that all voices are heard with respect and equity. I've learned from the experience - it has made me more strategic and more resilient in how I go about making my voice heard. It has built the strength of my relationships with my women colleagues so that we have sense of comradery, of mutual support born from shared frustration and anger.

Partnership can be seen to have positive implications for gender equity within and beyond partnership contexts through the creation of affirmative, equitable relationships. These relationships, when extended into the form of co-authorship, may also contribute to driving the findings found in Study One, where women have a wellestablished presence in contributing to partnership discourses through publishing.

\section{Discussion}

We explored the relationship between gender and SaP, addressing the question: To what extent are women's voices represented as part of knowledge production in SaP, and how does this shape their experiences in higher education? Our qualitative and quantitative results provide initial complementary evidence that SaP can create microcultures within higher education where women can assert their voices in both individual spaces and broader discourses. We note here that our aim was exploratory, rather than seeking to establish any certain outcomes. Indeed, in $\mathrm{SaP}$, literature points to 
a strong emphasis on processes rather than outcomes (Healey et al., 2014) and our findings, perhaps somewhat uncomfortably in an outcomes-driven sector, reflect that. Below, we discuss and explore three of the many potential areas of consideration arising from our data, each with implications for the wider sector.

\section{SaP research as 'brave spaces' and 'sites of resistance' against gendered norms}

Our analysis of SaP authorship showed that women constitute the majority of authors, including first authors, of SaP-related scholarship within our sample. This is consistent with patterns in other teaching and learning fields. McKinney and Chick (2010) for example, found that women were overrepresented, between 58 and 64 per cent, in scholarship of teaching and learning activities. Bernhagen and Gravett (2017) presented similar findings in the field of educational development. These trends are in stark contrast to disciplines that have typically been dominated by masculine narratives (Carey, Jackson, Antonello, \& Rushing, 2016), as is the case within STEM (Filardo et al., 2016) and certain areas of medicine (Jagsi et al., 2006), for example.

Since our findings indicate substantial contributions by women in $\mathrm{SaP}$ - both in terms of tangible outputs (i.e., publications) and personal experiences-we argue that SaP can be seen to create 'brave spaces' (Arao \& Clemens, 2013; Cook-Sather, 2016) or at times even 'sites of resistance' within which gendered norms may be countered. As illustrated by our qualitative findings, SaP was often a place where we felt comfortable speaking up to discuss, question, and sometimes even redefine, existing power hierarchies. Topics that often felt inappropriate or unsafe to discuss in other contexts — such as our experiences as women in higher education-were legitimized and given an opportunity to be discussed, studied, and more deeply understood. This allowed us to develop a sense of agency that is evident not only in our SaP-related work 
but has also translated into our roles as students, researchers, and employees within the university system more broadly.

Reflecting on what an 'ethos of female leadership' looks like, Baxter Magolda (as cited in Rogers, 1988) suggests that 'women's preferred model of learning includes hearing others, being open to saying what they feel, and encouraging others to express their views ... at the heart of the female ethos is the focus on relationships' (p. 3). This focus came through in our qualitative results in Study Two where the role of affirmative relationships among in women in $\mathrm{SaP}$ was critical for developing their own agency and leadership in promoting gender equity. Although we recognize that gender is socialized, fluid, and does not necessarily follow prescriptive binary norms, these differing leadership styles speak to socialized feminine and masculine gender roles. Thus, if socialized gender roles mean that women may construct meaning and knowledge differently than men (e.g., a greater focus on the relational), then women's leadership in $\mathrm{SaP}$ may be beneficial as it is a field that highlights the primacy of relationships (CookSather et al., 2014; Healey et al., 2014). Moreover, relational skills such as listening to and encouraging others are important for navigating SaP-related power dynamics (when faculty/staff interact with students, for instance).

Another advantage of $\mathrm{SaP}$ is that it does not only exist in a single, disciplinary context. Practitioners can and do come from a variety of disciplinary backgrounds, including nearly 40\% from the sciences (Mercer-Mapstone et al., 2017a). This has the potential to further the impact of $\mathrm{SaP}$ as a means of fostering equity in higher education, as it can enable participation even within those disciplines in which knowledge construction is traditionally seen as more hierarchical (Carey et al., 2016). 


\section{The potential devaluing of SaP as a gendered practice}

Our findings showed differences in the forms of scholarship that women tended to author. Although authorship in SaP tended to favour women for the majority of article types, including research articles, the largest gender difference in authorship was found among reflections. Eighty-three percent of reflections were authored by women and only $17 \%$ by men. On the one hand, this is not surprising given the relational nature of $\mathrm{SaP}$ - perhaps it is this genre, not limited by the more formal expectations of research articles, that lends itself most aptly to the consideration of practice (Cook-Sather, Abbot, \& Felten, 2019). On the other hand, this finding also raises troubling questions about whether authorship in this field continues, to some extent, to reflect the gendered norms of academia when it comes to authoring articles that tend to be normatively considered as less 'rigorous.' Mercer-Mapstone and Mercer (2017) pointed out that 'aspects of rigorous or scholarly writing are, historically speaking, masculinist' (p. 152), which may lead to the undervaluing of less traditional forms of scholarship, such as reflections (Cook-Sather et al., 2019; Knights \& Richards, 2003).

Similar questions may be raised by the impact of scholarly work in $\mathrm{SaP}$, as reported in Study One. Although it is promising that we did not find a significant difference in citation counts between women and men, the average citation count per article in $\mathrm{SaP}$ was lower than in other social sciences disciplines (2.90 vs. 4.67; Times Higher Education, 2011). Similarly, although there were no significant gender differences, the average h-index of authors publishing in SaP was substantially lower than in the social sciences as a whole (7.44 vs. 40.03; Malesios \& Psarakis, 2014). This may in part be reflective of $\mathrm{SaP}$ as an emerging field, with many authors being students and early-career researchers. This might also explain why the majority of the first authors in our sample did not have academic profiles on Google Scholar or ResearchGate. If this is the case, then it could be seen as positive that SaP gives voice to 
individuals who may not traditionally have the opportunity to contribute to academic discourses and can help new scholars to develop the skills they need to work effectively within and beyond academia (Matthews, 2017). On the other hand, however, these findings may also indicate that $\mathrm{SaP}$ has not yet attained the same level of academic impact and legitimacy as other disciplines, at least when using more conventional measures of research impact.

Instead of serving to counter traditional norms of academic publishing, then, does this trend instead serve to devalue $\mathrm{SaP}$ as a legitimate and respected area of scholarship and practice? This has been the case in teaching and learning, more broadly, when conceptualised as a service industry and similar arguments have been made elsewhere. For example, McKinney and Chick (2010) argued that 'women are more likely than men to be socialized to focus on and be comfortable with "emotion work", (p. 2), which may lead them to disproportionately be involved in tasks that emphasize caring, empathy, and service provision (El-Alayli, Hansen-Brown, \& Ceynar, 2018). As one example of this, Healey and Davies (2019) found that women tended to conceptualise 'research' more broadly than men, linking their definitions to teaching activities such as postgraduate research supervision or using research to inform their teaching. Guy and Newman (2004) argue that because emotive tasks such as 'caring, negotiating, empathizing, smoothing troubled relationships, and working behind the scenes to enable cooperation' are seen as 'natural' to women, the labour they require becomes invisible (p. 289). Indeed, some of the most nourishing aspects of the partnerships described in the reflections in Study Two were those that reflect nurturing behaviours, making those behaviours appear central to functioning partnerships.

Emotionally laborious work is not formalized in job descriptions or performance evaluations, and as a result, often remains uncompensated and unacknowledged. This 
may help to explain some of the challenges that SaP practitioners, like educational developers, may face in 'getting "invited to the table" ... [or] becoming more involved in organizational development efforts' (Bernhagen \& Gravett, 2017, para. 1). It is clear that emotional labour is necessary in $\mathrm{SaP}$ work, due to its highly relational nature (Felten, 2017). However, given indications that emotional labour tends to be undervalued, it is important to question whether or not work in $\mathrm{SaP}$ is undervalued also.

Another risk of viewing emotionally laborious work through a gendered lens is that of essentialising gender and binary ways of thinking. It is not our intention, for example, to suggest that it is only women who undertake such work or are uncompensated for their efforts. Emotional labour-regardless of who it is performed by-remains heavily undervalued both within higher education and society as a whole.

Despite these risks, we maintain that the emotional nature of $\mathrm{SaP}$ is core to its value. Instead of undervaluing emotional labour, engagement in $\mathrm{SaP}$ could perhaps engender a culture shift where emotional labour becomes more valued and prevalent. As Meier, Mastracci, and Wilson (2006) showed, emotional labour makes organizations run more smoothly and is a necessary aspect of any workplace; thus, greater performance of emotive tasks from academics of all genders - and greater acceptance of this as the norm - is likely to improve the functioning of academic workplaces.

\section{Building agency and leadership through SaP}

A recent report of women in leadership positions in universities across the United Kingdom found that four in five university vice-chancellors or chairs of university governing bodies are men, with men still retaining the vast majority of academic head and executive roles (Jarboe, 2016a). This is also the case in Australia (Jarboe, 2016b) and North America (American Association of University Professors, 2009). McKinney and Chick (2010) argued that, due to discrimination and societal differences in power 
and status, women face " "glass walls" that create a horizontal segregation across occupations' and "'glass ceilings" that create a vertical segregation within single occupations' (p. 2). For example, women face distinct and disproportionate challenges in undertaking doctoral studies (Carter, Blumenstein, \& Cook, 2013) - just one of the many barriers hindering their progression into senior academic roles.

If higher education is to move away from role segregation along such gendered lines, then we suggest that changes need to occur from the very infancy of any potential academic career — namely, the environment into which students are enculturated from day one. We suggested earlier that the skills developed through partnership are well situated to engender behaviours that promote gender equity. The complementarity of our results speaks to this. Study Two indicated that partnership can develop a sense of agency in women practitioners such that they seek to assert their own voices and amplify those of others. The development of such agency may contribute to the findings of Study One such that, when women engage in partnership, they may be more likely to publish on their practices, thus asserting their voices in a broader sphere as a result. This is not to suggest that it is exclusively women that must change to fit the mould of a patriarchal system; rather, it is suggestive of one way in which we may be able to amplify women's voices while still working towards larger, systems-level solutions.

We can look to literature on SaP authored or co-authored by students for firsthand accounts of how partnership experiences for students can be empowering in developing agency, resilience, and leadership within the university sphere. Mathrani (2018), for example, describes the personal growth she felt through experiences working as a student in pedagogical partnership that impacted her agency not only within the partnership but in her life beyond, as well: 
Through my journey of building relationships and navigating discomfort and uncertainty, I developed a stronger belief in myself. In the context of my partnerships I have felt valued and confident. However, contexts outside my partnerships provided me the opportunity to witness how my positive engagement with the [partnership] program can permeate all facets of my life. (p. 5)

Ntem and Cook-Sather (2018), exploring the experiences of ten women in partnership, found that students felt they overcame self-doubt and developed personal, professional, and psychological resilience in the face of adversity when working in the power-laden, hierarchical contexts of higher education: 'When student partners choose approaches to respond to what they perceive to be "pervasive power," these approaches influence the forms of resilience they develop' (p. 12).

There are many more examples in which students articulate the ways in which partnership impacts their own sense of self (e.g., Wynkoop, 2018), their belief in the value of their voice (e.g., Acai, Kirby, \& Shammas, 2017b), their ability to overcome adversity and power asymmetries (e.g., Reyes \& Adams, 2017), and their capacity for leadership and agency to create positive change within and beyond university contexts (e.g., Ntem, 2016). These are arguably some of the skills that are critical in supporting women in progressing into and thriving in academic careers or leadership positions, and to promoting a larger culture shift to support such gender equity. To this end, partnership can create greater awareness of equity-related issues among all involved, which can help to facilitate broader cultural change. Wynkoop (2018), for example, shared that '. . given my identity as a white male, I felt as though I came to understand more deeply [through partnership] just how crucial giving space to people of other, often marginalized identities is ... I now make inclusion an even more important principle I aim to enact and achieve' (p. 3). The combination of this previous research 
and our own results thus supports the proposition that partnership can indeed present one approach to creating more equitable systems of higher education.

\section{Limitations and future research}

We faced a number of limitations that readers should be aware of when considering our results. First, while the dataset from Study One was drawn from journals known for publishing SaP work, other journals also publish such work and those bodies of literature were excluded from our sample, as was work published outside academic journals. Such exclusions are necessary for any such study in bounding the scope of research (Kennedy, 2007). Readers should take caution, however, in extrapolating the implications of this study beyond our analysed sample. We also caution readers when interpreting the h-indices reported in Study One. Since we were unable to locate hindices for the majority of the first authors in our sample, the mean h-indices reported may be inflated as it is most likely to be students and other junior researchers who do not have academic profiles on Google Scholar or ResearchGate. These and other findings from Study One indicate a need to look at more than just conventional measures of research impact when considering the merits of a field, as there are many reported benefits of SaP that relate to the process and not just the outputs (Acai et al., 2017a; Cook-Sather et al., 2014).

We are also aware that our analysis for Study One may have resulted in the possibility of misgendering authors within our sample. While precautions were taken to avoid this, there remains the risk that our own implicit assumptions were projected onto the analysis process, as with any research conducted through a specific sociocultural lens. Similarly, we note that the conceptions of gender used in this study were shaped by our Western sociocultural context meaning that, while being mindful of seeing gender identity as a spectrum rather than as binaries, our results do unintentionally 
binarize gender. This is ultimately a reflection of the social lens we bring to this research and the social context that produced our data sources. We also acknowledge that different cultural conceptions of gender were not considered primarily because of the predominantly Western-centric nature of the partnership literature. Studies in other sociocultural contexts would be a fruitful avenue for future exploration.

Limitations of Study Two are those common to many small-scale qualitative studies. Our sample was small, as is appropriate for in-depth collaborative autoethnographic studies that do not strive for generalisability but rather deeper, thicker nuance (Chang et al., 2013). Results were intended to provide an additional angle through which to complement quantitative data and should be extrapolated with caution. Similarly, we come from relatively privileged white upbringings, so our data do not speak to the barriers faced by women from other socio-cultural positions. Mohanty (1989), for example, refers specifically to 'Third World women' and not white women in her essay ${ }^{6}$ — while we draw upon her conceptual lens in our research (and those of other feminist scholars), we emphasize the importance of elevating women of colour's voices and subjectivity. Future studies exploring the experiences of women from other social contexts and cultures are a necessary addition to this burgeoning field.

Finally, we wish to acknowledge that we risk over-generalising when we refer to gender inequity across the postsecondary sector. While this is an ongoing issue in many contexts, there are also a number of universities - with men, women, and gender nonbinary advocates - leading the way in redressing such asymmetries. While our approach may be seen by some to reinscribe the gendered, binary categorizations that are the norm, we also see it as an important way of highlighting inequities and pushing for

\footnotetext{
${ }^{6}$ In her essay, 'On Race and Voice: Challenges for Liberal Education in the 1990s,' Mohanty (1989) argues against 'feminist scholarship [that is] uncritically grounded in Western humanism and its modes of "disinterested scholarship"” (p. 180). In using autoethnography as part of our work, we also push against Western humanist 'disinterested scholarship.'
} 
progressive change within our existing system. Future practice could, for example, apply the findings of this study and use partnership to actively engage women-identified students through targeted initiatives that aim to enhance experiences and build capacities such as leadership and resilience, which may drive higher retention within academia. These should not be seen as isolated fixes, however, and we recommend such initiatives happen in concert with other efforts that encourage culture change and reduce the root causes of gender inequity in higher education.

\section{Conclusion}

Gender inequity continues to be a challenge in higher education systems. We explored the idea that engaging SaP may be one approach to research and practice that has the potential to help redress this issue. The complementarity of our qualitative and quantitative results supports this proposition. Results from an analysis of gender distributions of authors of partnership work across six higher education journals showed that the majority of authors of SaP articles were women and the majority of articles had a woman lead author. Findings from our own reflective narratives as women SaP practitioners indicated that affirmative partnerships built our agency in asserting our own voices and encouraging others to do the same.

This initial evidence suggests that $\mathrm{SaP}$ represents a space where women can assert their voices and become leaders in knowledge production both in individual contexts (e.g., within their workplaces) and more broadly in the scholarly literature. We argue that these 'brave spaces' and 'sites of resistance' against patriarchal academic norms represent one area in which women can develop the skills and agency required to establish themselves and take on leadership roles in university environments.

One of the strengths we see in this space is that SaP practices can take place in any discipline, creating microcultures where relationships are valued, and agency is 
fostered within fields that might otherwise have hierarchical forms of knowledge construction. A significant challenge, however, is that even within publishing, women may tend to take on emotionally labour-intensive roles. We caution SaP practitioners to be aware of such trends, which may be one contributor to the devaluation of the field, as has been identified in other similar areas of scholarship and practice. Overall, however, we find our results to be encouraging. They indicate that SaP offers a way of thinking and doing in higher education that has benefits for all genders as well as broader university communities in so far as it creates spaces for inequitable power structures to be revealed, examined, and ultimately, redressed.

Acknowledgements: Our sincere thanks to Mike Galang and Kiret Dhindsa for their statistical input.

\section{References}

Aiston, S., \& Jung, J. (2015). Women academics and research productivity: An international comparison. Gender and Education, 27(3), 205-220. https://doi.org/10.1080/09540253.2015.1024617

Acai, A., Akesson, B., Allen, M., Chen, V., Mathany, C., McCollum, B., . . Vervoord, R. E. M. (2017a). Conceptualizations of success in student-faculty/staff SoTL partnerships: Motivations, challenges, power, and definitions. The Canadian Journal for the Scholarship of Teaching and Learning, 8(2). https://doi.org/10.5206/cjsotl-rcacea.2017.2.8

Acai, A., Kirby, S., \& Shammas, R. (2017b). Reflections on an international 'change institute' for students as partners: A student perspective. International Journal for Students as Partners, 1(1). https://doi.org/10.15173/ijsap.v1i1.3084

Allin, L. (2014). Collaboration between staff and students in the Scholarship of Teaching and Learning: The potential and the problems. Teaching \& Learning Inquiry: The ISSOTL Journal, 2(1), 95-102.

https://doi.org/10.2979/teachlearninqu.2.1.95

American Association of University Professors. (2009). On the brink: The annual report on the economic status of the profession, 2008-09. Washington, DC: American Association of University Professors. Retrieved from 
https://www.aaup.org/NR/rdonlyres/0A07ADBE-930F-461E-9140-

\section{C74F24122949/0/zreport.pdf}

Amundsen, C., \& Wilson, M. (2012). Are we asking the right questions? A conceptual review of the educational development literature in higher education. Review of Educational Research, 82(1), 90-126.

\section{https://doi.org/10.3102/0034654312438409}

Arao, B., \& Clemens, K. (2013). From safe spaces to brave spaces: A new way to frame dialogue around diversity and social justice. In L. M. Landreman (Ed.), The art of effective facilitation: Reflections from social justice educators (pp. 135-150). Sterling, VA: Stylus.

Bernhagen, L., \& Gravett, E. (2017). Educational development as pink collar labor: Implications and recommendations. To Improve the Academy, 36(1), 9-19. https://doi.org/10.1002/tia2.20053

Borwein, S. (2014). The great skills divide: A review of the literature. Toronto, ON: Higher Education Quality Council of Ontario. Retrieved from http://www.heqco.ca/SiteCollectionDocuments/Skills\%20Part\%201.pdf

Bovill, C., Cook-Sather, A., Felten, P., Millard, L., \& Moore-Cherry, N. (2016). Addressing potential challenges in co-creating learning and teaching: Overcoming resistance, navigating institutional norms and ensuring inclusivity in student-staff partnerships. Higher Education, 71(2), 195-208. https://doi.org/10.1007/s10734-015-9896-4

Braun, V., \& Clarke, V. (2006). Using thematic analysis in psychology. Qualitative Research in Psychology, 3(2), 77-101. https://doi.org/10.1191/1478088706qp063oa

Burke, P. J. (2015). Re/imagining higher education pedagogies: Gender, emotion and difference. Teaching in Higher Education, 20(4), 388-401. https://doi.org/10.1080/13562517.2015.1020782

Canadian Institutes of Health Research (2018). How to integrate sex and gender into research. Retrieved from http://www.cihr-irsc.gc.ca/e/50836.html

Carey, M., Jackson, M., Antonello, A., \& Rushing, J. (2016). Glaciers, gender, and science: A feminist glaciology framework for global environmental change research. Progress in Human Geography, 40(6), 770-793. https://doi.org/10.1177/0309132515623368 
Carr, B. (1993). “A woman speaks ... I am a woman and not white”: Politics of voice, tactical essentialism, and cultural intervention in Audre Lorde's activist poetics and practice. College Literature, 20(2), 133-153.

Carter, S., Blumenstein, M., \& Cook, C. (2013). Different for women? The challenges of doctoral studies. Teaching in Higher Education, 18(4), 339-351. https://doi.org/10.1080/13562517.2012.719159

Chang, H., Ngunjiri, F., \& Hernandez, W. (2013). Collaborative autoethnography. London, England: Routledge.

Clandinin, D. J., \& Connelly, F. M. (2000). Narrative inquiry: Experience and story in qualitative research. San Francisco, CA: Jossey-Bass.

Cook-Sather, A. (2015). Dialogue across differences of position, perspective, and identity: Reflective practice in/on a student-faculty pedagogical partnership program. Teachers College Record, 117(2), 1-42. Retrieved from https://repository.brynmawr.edu/edu_pubs/32/

Cook-Sather, A. (2016). Creating brave spaces within and through student-faculty pedagogical partnerships. Teaching and Learning Together in Higher Education, 18. Retrieved from

https://repository.brynmawr.edu/cgi/viewcontent.cgi?article=1143\&context=tlth $\underline{\mathrm{e}}$

Cook-Sather, A., Abbot, S., \& Felten, P. Legitimating reflective writing in SoTL: "Dysfunctional illusions of rigor" revisited. Teaching \& Learning Inquiry, 7(2). https://doi.org/10.20343/teachlearninqu.7.2.2

Cook-Sather, A., \& Agu, P. (2013). Students of color and faculty members working together toward culturally sustaining pedagogy. To Improve the Academy, 32(1), 271-285. https://doi.org/10.1002/j.2334-4822.2013.tb00710.x

Cook-Sather, A., Bovill, C., \& Felten, P. (2014). Engaging students as partners in learning and teaching: A guide for faculty. San Francisco, CA: Jossey-Bass.

Cook-Sather, A., \& Luz, A. (2015). Greater engagement in and responsibility for learning: What happens when students cross the threshold of student-faculty partnership. Higher Education Research \& Development, 34(6), 1097-1109. https://doi.org/10.1080/07294360.2014.911263

Dunne, E., \& Zandstra, R. (2011). Students as change agents: New ways of engaging with learning and teaching in higher education. Bristol, England: Higher Education Academy. Retrieved from http://escalate.ac.uk/downloads/8242.pdf 
El-Alayli, A., Hansen-Brown, A. A., \& Ceynar, M. (2018). Dancing backwards in high heels: Female professors experience more work demands and special favor requests, particularly from academically entitled students. Sex Roles, 1-15. https://doi.org/10.1007/s11199-017-0872-6

European Commission (2012). She figures 2012: Gender in research and innovation.

Luxembourg: Directorate-General for Research and Innovation of the European Commission. Retrieved from http://ec.europa.eu/research/sciencesociety/document_library/pdf_06/she-figures-2012_en.pdf

European Union (2012). The EU in the world 2013: A statistical portrait. Luxembourg: Publications Office of the European Union. Retrieved from http://ec.europa.eu/eurostat/documents/3217494/5786625/KS-EX-14-001EN.PDF

Felten, P. (2017). Emotion and partnerships. International Journal for Students as Partners, 1(2). https://doi.org/10.15173/ijsap.v1i2.3070

Filardo, G., da Graca, B., Sass, D. M., Pollock, B. D., Smith, E. B., \& Martinez, M. A.M. (2016). Trends and comparison of female first authorship in high impact medical journals: Observational study (1994-2014). BMJ, 352, i847. https://doi.org/10.1136/bmj.i847

Fredricks, J. A., Blumenfeld, P., \& Paris, A. (2004). School engagement: Potential of the concept, state of the evidence. Review of Educational Research, 74(1), 59109. https://doi.org/10.3102/00346543074001059

Guy, M. E., \& Newman, M. A. (2004). Women's jobs, men's jobs: Sex segregation and emotional labour. Public Administration Review, 64(3), 289-298. https://doi.org/10.1111/j.1540-6210.2004.00373.x

Hango, D. (2013). Gender differences in science, technology, engineering, mathematics and computer science (STEM) programs at university. Ottawa, ON: Statistics Canada. Retrieved from https://www150.statcan.gc.ca/n1/en/pub/75-006$\underline{\mathrm{x} / 2013001 / \text { article/11874-eng.pdf? st=JSMBSI9X }}$

Haraway, D. (1988). Situated knowledges: The science question in feminism and the privilege of partial perspective. Feminist Studies, 14(3), 575-599. https://doi.org/10.2307/3178066

Healey, M., Flint, A., \& Harrington, K. (2014). Engagement through partnership: Students as partners in learning and teaching in higher education. York, England: Higher Education Academy. Retrieved from 
https://www.heacademy.ac.uk/system/files/resources/engagement through_part nership.pdf

Healey, M., Flint, A., \& Harrington, K. (2016). Students as partners: Reflections on a conceptual model. Teaching \& Learning Inquiry: The ISSOTL Journal, 4(2). https://doi.org/10.20343/teachlearninqu.4.2.3

Healey, R., \& Davies, C. (2019). Conceptions of 'research' and their gendered impact on research activity: A UK case study. Higher Education Research \& Development, 38(7), 1386-1400. https://doi.org/10.1080/07294360.2019.1657804

Hirsch, J. E. (2005). An index to quantify an individual's scientific research output. Proceedings of the National Academy of Sciences of the United States of America, 102(46), 16569-16572. https://doi.org/10.1073/pnas.0507655102

Hugo Lopez, M., \& Gonzalez-Barrera, A. (2014). Women's college enrollment gains leave men behind. Retrieved from http://www.pewresearch.org/facttank/2014/03/06/womens-college-enrollment-gains-leave-men-behind/

Jagsi, R., Guancial, E. A., Worobey, C. C., Henault, L. E., Chang, Y., Starr, R., . . Hylek, E. M. (2006). The 'gender gap' in authorship of academic medical literature-A 35-year perspective. The New England Journal of Medicine, 355(3), 281-287. https://doi.org/10.1056/NEJMsa053910

Jarboe, N. (2016a). WomenCount: Leaders in higher education 2016. Retrieved from: https://womencountblog.files.wordpress.com/2016/04/women-countreport web final.pdf

Jarboe, N. (2016b). WomenCount: Australian Universities 2016. Retrieved from: https://womencountblog.files.wordpress.com/2017/03/womencount-autralianreport_screen-res.pdf

Kahu, E. R., \& Nelson, K. (2018). Student engagement in the educational interface: Understanding the mechanisms of student success. Higher Education Research \& Development, 37(1), 58-71. https://doi.org/10.1080/07294360.2017.1344197

Kaur, A., Awang-Hashim, R., \& Kaur, M. (2018). Students' experiences of co-creating classroom instruction with faculty- a case study in eastern context. Teaching in Higher Education, 1-17. https://doi.org/10.1080/13562517.2018.1487930

Kennedy, M. M. (2007). Defining a literature. Educational Researcher, 36(3), 139-147. https://doi.org/10.3102/0013189X07299197 
Klein, U. (2016). Gender equality and diversity politics in higher education: Conflicts, challenges and requirements for collaboration. Women's Studies International Forum, 54,147-156. https://doi.org/10.1016/j.wsif.2015.06.017

Malesios, C., \& Psarakis, S. (2014). Comparison of the h-index for different fields of research using bootstrap methodology. Quality \& Quantity, 48(1), 521-545. https://doi.org/10.1007/s11135-012-9785-1

Marquis, E., Black, C., \& Healey, M. (2017). Responding to the challenges of studentstaff partnership: The reflections of participants at an international summer institute. Teaching in Higher Education, 1-16.

https://doi.org/10.1080/13562517.2017.1289510

Mathrani, S. (2018). Building relationships, navigating discomfort and uncertainty, and translating my voice in new contexts. Teaching and Learning Together in Higher Education, 23. Retrieved from https://repository.brynmawr.edu/tlthe/vol1/iss $23 / 6$

Matthews, K. E. (2017). Five propositions for genuine students as partners practice. International Journal for Students as Partners, 1(2). https://doi.org/10.15173/ijsap.v1i2.3315

Matthews, K. E., Cook-Sather, A., \& Healey, M. (2018). Connecting learning, teaching, and research through student-staff partnerships: Toward universities as egalitarian learning communities. In V. Tong, A. Standen, \& M. Sotiriou (Eds.), Research equals teaching: Inspiring research-based education through studentstaff partnerships. London, England: UCL Press.

McKinney, K., \& Chick, N. L. (2010). SoTL as women's work: What do existing data tell us? International Journal for the Scholarship of Teaching and Learning, 4(2). https://doi.org/10.20429/ijsotl.2010.040216

Meier, K. J., Mastracci, S. H., \& Wilson, K. (2006). Gender and emotional labor in public organizations: An empirical examination of the link to performance. Public Administration Review, 66(6), 899-909. https://doi.org/10.1111/j.1540$\underline{6210.2006 .00657 . x}$

Mercer-Mapstone, L., Dvorakova, S. L., Groenendijk, L., \& Matthews, K. E. (2017b). Idealism, conflict, leadership, and labels: Reflections on co-facilitation as partnership practice. Teaching and Learning Together in Higher Education, 1(21). Retrieved from https://repository.brynmawr.edu/tlthe/vol1/iss21/8/ 
Mercer-Mapstone, L., Dvorakova, S. L., Matthews, K. E., Abbot, S., Cheng, B., Felten, P., ... Swaim, K. (2017a). A systematic literature review of students as partners in higher education. International Journal for Students as Partners, 1(1). https://doi.org/10.15173/ijsap.v1i1.3119

Mercer-Mapstone, L., \& Mercer, G. (2017). A dialogue between partnership and feminism: deconstructing power and exclusion in higher education. Teaching in Higher Education, 23(1), 137-143.

https://doi.org/10.1080/13562517.2017.1391198

Mohanty, C. T. (1989). On race and voice: Challenges for liberal education in the 1990s. Cultural Critique, 14, 179-208. https://doi.org/10.2307/1354297

Ntem, A. (2016). Learning to be brave within and beyond partnership. Teaching and Learning Together in Higher Education, 18. Retrieved from https://repository.brynmawr.edu/tlthe/vol1/iss18/6/

Ntem, A., \& Cook-Sather, A. (2018). Resistances and resiliencies in pedagogical partnership: Student partners' perspectives. International Journal for Students as Partners, 2(1). https://doi.org/10.15173/ijsap.v2i1.3372

Reed-Danahay, D. (1997). Auto/ethnography: Rewriting the self and the social. Oxford, England: Berg.

Reyes, V., \& Adams, K. (2017). A partnership approach to managing the challenge of apathetic and disruptive students. Teaching and Learning Together in Higher Education, 22. Retrieved from https://repository.brynmawr.edu/tlthe/vol1/iss22/4/

Rogers, J. L. (1988). New paradigm leadership: Integrating the female ethos. Initiatives, 51(4), 1-8.

Seale, J., Gibson, S., Haynes, J., \& Potter, A. (2015). Power and resistance: Reflections on the rhetoric and reality of using participatory methods to promote student voice and engagement in higher education. Journal of Further and Higher Education, 39(4), 534-552. https://doi.org/10.1080/0309877X.2014.938264

Times Higher Education. (2011). Citation averages, 2000-2010, by fields and years. Retrieved from https://www.timeshighereducation.com/news/citation-averages2000-2010-by-fields-and-years/415643.article

University of Brighton. (2011). Critical incident analyses [Course notes]. Brighton: University of Brighton. 
Workplace Gender Equality Agency. (2018). Higher education enrolments and graduate labour market statistics. Sydney, Australia: Workplace Gender Equality Agency. Retrieved from

https://www.wgea.gov.au/sites/default/files/graduate-labour-marketstatistics.pdf

Wynkoop, P. (2018). My transformation as a partner and a learner. Teaching and Learning Together in Higher Education, 23. Retrieved from https://repository.brynmawr.edu/tlthe/vol1/iss23/4/ 
Figure 1. Gender distribution of authors, by article type.

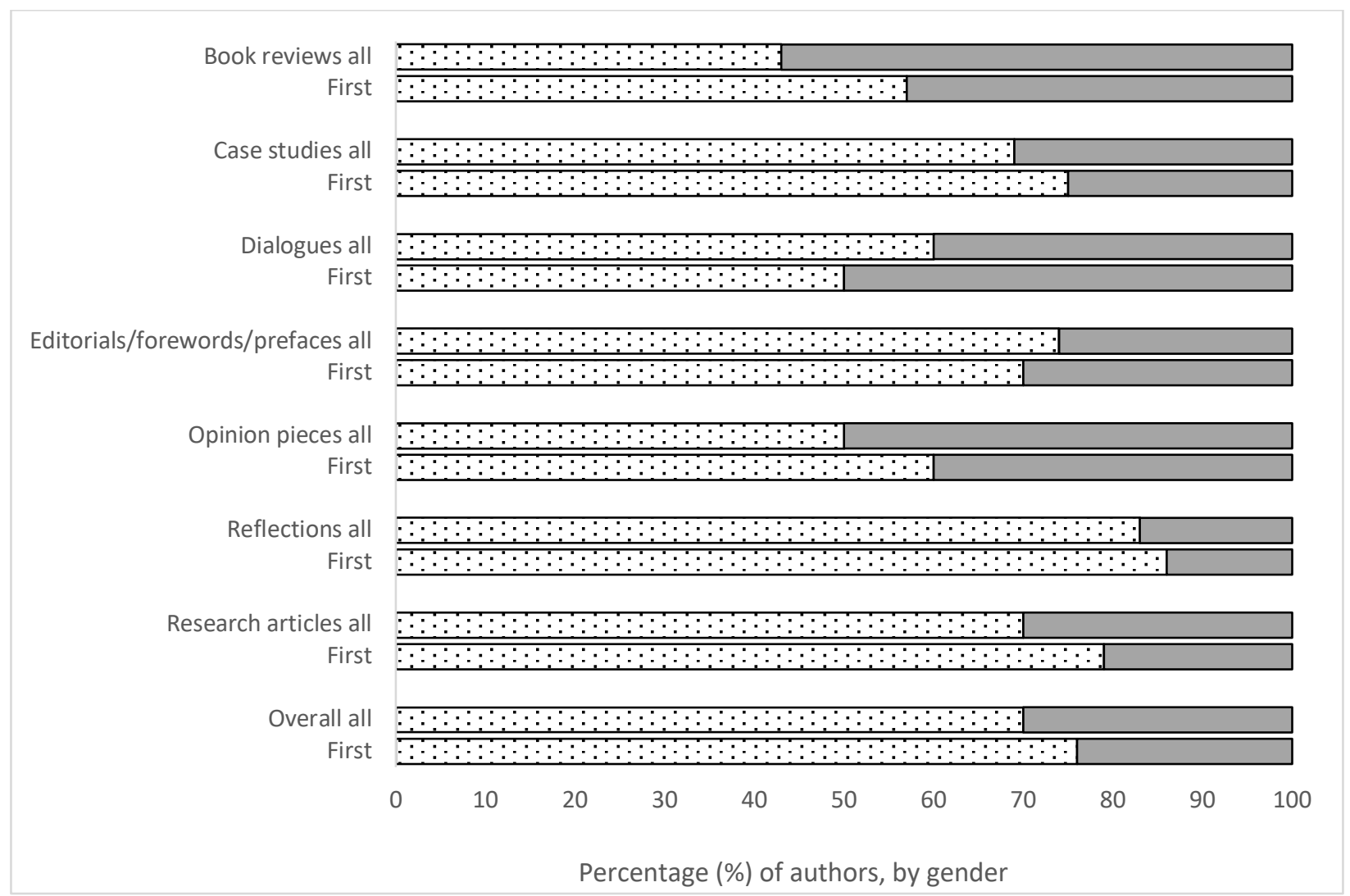


Figure 2. Trends in women's authorship over time.

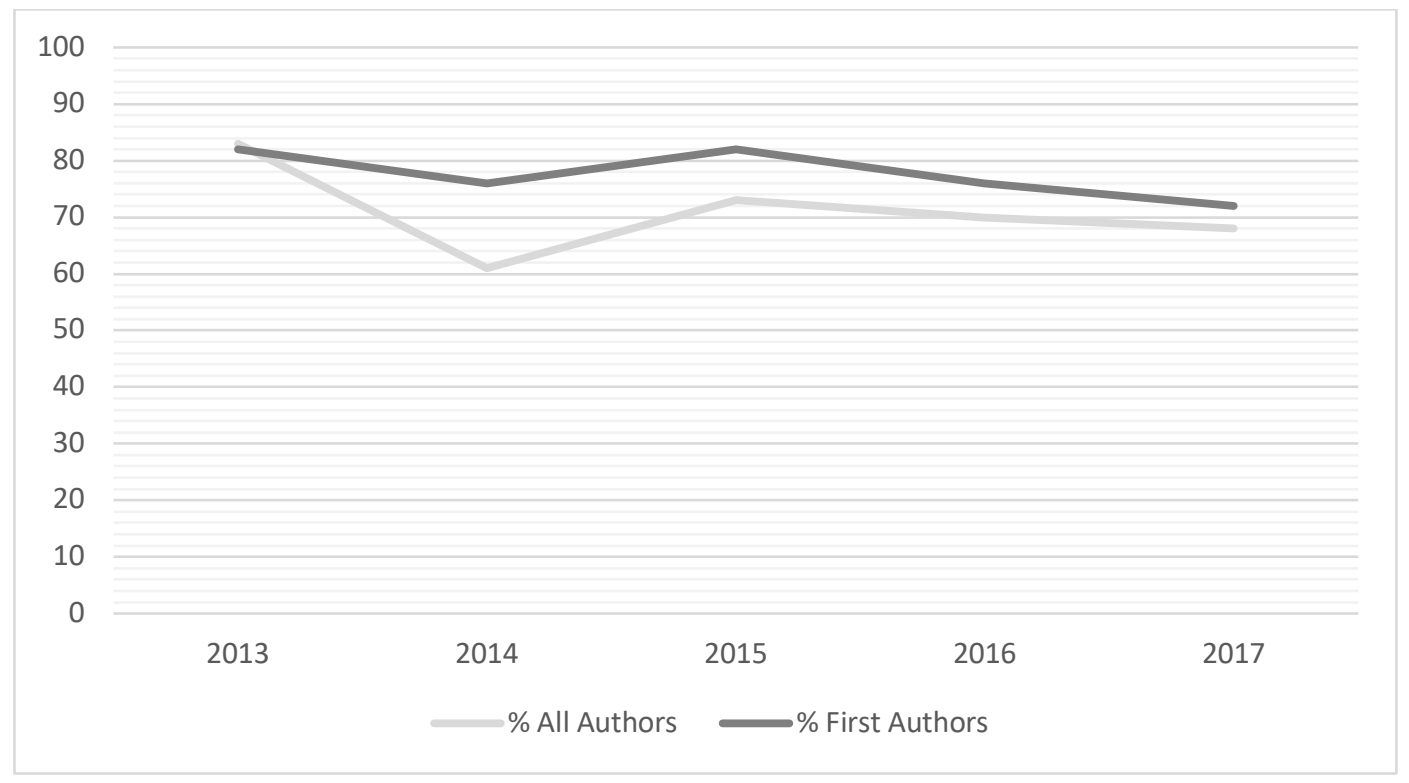


Table 1. Citation counts and percentage (\%) of all authors and first authors who are women, by journal.

\begin{tabular}{|c|c|c|}
\hline Journal title & $\begin{array}{l}\text { Percentage of authors } \\
\text { who are women }\end{array}$ & $\begin{array}{l}\text { Percentage of articles with } \\
\text { women as first authors }\end{array}$ \\
\hline $\begin{array}{l}I J A D(n=15) \\
\text { Avg. citation count: } 15.71\end{array}$ & $28 / 42(67)$ & $13 / 15(87)$ \\
\hline $\begin{array}{l}\text { IJSaP }(n=29) \\
\text { Avg. citation count: } 2.62\end{array}$ & $63 / 95(66)$ & $21 / 29(72)$ \\
\hline $\begin{array}{l}J E I P C(n=41) \\
\text { Avg. citation count: } 1.20\end{array}$ & $75 / 113(66)$ & $26 / 41(63)$ \\
\hline $\begin{array}{l}S E H E J(n=13) \\
\text { Avg. citation count: } 2.92\end{array}$ & $24 / 33(73)$ & $11 / 13(85)$ \\
\hline $\begin{array}{l}T L I(n=11) \\
\text { Avg. citation count: } 12.82\end{array}$ & $24 / 31(77)$ & $6 / 11(55)$ \\
\hline $\begin{array}{l}\text { TLTHE }(n=93) \\
\text { Avg. citation count: } 0.65\end{array}$ & $145 / 198(73)$ & $77 / 93(83)$ \\
\hline All journals $(n=202)$ & $359 / 512(70)$ & $154 / 202(76)$ \\
\hline
\end{tabular}


Table 2. Percentage (\%) of all authors and first authors who are women, by year.

\begin{tabular}{lllll}
\hline $\begin{array}{l}\text { Year of } \\
\text { publication }\end{array}$ & $\begin{array}{l}\text { Percentage of } \\
\text { authors who are } \\
\text { women }\end{array}$ & $\begin{array}{l}\text { \% change } \\
\text { from } \\
\text { previous } \\
\text { year }\end{array}$ & $\begin{array}{l}\text { Percentage of } \\
\text { articles with } \\
\text { women as first } \\
\text { authors }\end{array}$ & $\begin{array}{l}\text { \% change } \\
\text { from } \\
\text { previous } \\
\text { year }\end{array}$ \\
\hline $2013(n=22)$ & $30 / 36(83)$ & -- & $18 / 22(82)$ & -- \\
\hline $2014(n=21)$ & $20 / 33(61)$ & -22 & $16 / 21(76)$ & -6 \\
\hline $2015(n=38)$ & $73 / 100(73)$ & +12 & $31 / 38(82)$ & +6 \\
\hline $2016(n=49)$ & $95 / 135(70)$ & -3 & $37 / 49(76)$ & -6 \\
\hline $2017(n=72)$ & $141 / 208(68)$ & -2 & $52 / 72(72)$ & -4 \\
\hline All years $(\boldsymbol{n}=\mathbf{2 0 2})$ & $\mathbf{3 5 9 / 5 1 2 ( 7 0 )}$ & -- & $\mathbf{1 5 4 / 2 0 2 ( 7 6 )}$ & -- \\
\hline
\end{tabular}


Table 3. Citation counts and percentage (\%) of all authors and first authors who are women, by article type.

\begin{tabular}{lll}
\hline Article type & $\begin{array}{l}\text { Percentage of authors } \\
\text { who are women }\end{array}$ & $\begin{array}{l}\text { Percentage of articles with } \\
\text { women as first authors }\end{array}$ \\
\hline $\begin{array}{l}\text { Book reviews }(n=7) \\
\text { Avg. citation count: } 0\end{array}$ & $3 / 7(43)$ & $4 / 7(57)$ \\
\hline $\begin{array}{l}\text { Case studies }(n=72) \\
\text { Avg. citation count: } 64\end{array}$ & $141 / 204(69)$ & $54 / 72(75)$ \\
\hline $\begin{array}{l}\text { Dialogues }(n=4) \\
\text { Avg. citation count: } 1.25\end{array}$ & $6 / 10(60)$ & $2 / 4(50)$ \\
\hline $\begin{array}{l}\text { Editorials/forewords/prefaces }(n=10) \\
\text { Avg. citation count: } 5.50\end{array}$ & $17 / 23(74)$ & $7 / 10(70)$ \\
\hline $\begin{array}{l}\text { Opinion pieces }(n=10) \\
\text { Avg. citation count: } 5.00\end{array}$ & $8 / 16(50)$ & $6 / 10(60)$ \\
\hline $\begin{array}{l}\text { Reflections }(n=37) \\
\text { Avg. citation count: } 1.73\end{array}$ & & $32 / 37(86)$ \\
\hline $\begin{array}{l}\text { Research articles }(n=62) \\
\text { Avg. citation count: } 5.87\end{array}$ & $52 / 63(83)$ & $\mathbf{1 5 4 / 2 0 2}(\mathbf{7 6})$ \\
\hline $\begin{array}{l}\text { All article types }(\boldsymbol{n}=\mathbf{2 0 2}) \\
\text { (n) }\end{array}$ & $132 / 189(70)$ & $49 / 62(79)$ \\
\hline
\end{tabular}

